\title{
PREDATORS OF BOOPEDON NUBILUM (SAY) SWARMS (ORTHOPTERA: ACRIDIDAE: GOMPHOCERINAE), DURING THREE DRIEST YEARS IN A TOBOSA GRASS PRAIRIE IN DURANGO, MEXICO
}

Rivera-García, E. 2011. Depedadores de enjambres de Boopedon nubilium (Say) (Orthoptera: Acrididae: Gomphocerinae), durante tres años secos en una pradera de pasto tobosa en Durango, México. Acta Zoológica Mexicana (n. s.), 27(3): 867-870.

RESUMEN. Los depredadores de saltamontes Boopedon nubilium fueron registrados de septiembre a octubre de 1998, 1999 y 2005 en la Reserva de la Biosfera de Mapimí. Esta especie tiende a formar grandes agregaciones que representan una fuente de alimento para muchas especies de vertebrados e invertebrados. La lista de depredadores de este saltamontes incluye cinco mamíferos, cinco reptiles, dos anfibios y 20 aves, mientras que los invertebrados incluyen seis insectos diurnos, seis arañas y cuatro artrópodos nocturnos.

Predation probe to be a strong selection pressure on herbivore insects (Mooney 2006, Mooney \& Linhart 2006), such as grasshoppers (Otte \& Joern 1975, Rees 1973); vertebrate predators are an important natural source to diminish their densities, with diverse implications on grasshopper behavior (McEwen et al. 2000), species composition, community structure, and specific modifications on strategies to avoid predation (Joern 1986, Fowler et al. 1991, Fuller \& Joern 1996, Pitt 1999, Van Bael \& Brown 2005, Branson 2005, Rivera-García \& Cano-Santana 2009).

This report focuses on predators of Boopedon nubilum (Say) in a Chihuahuan Desert arid grassland (weather defined by $\mathrm{T}_{\text {mean }} 20^{\circ} \mathrm{C}$; rainfall $263 \mathrm{~mm}$, and 2, 796 $\mathrm{mm}$ evaporation), located in Mapimí Biosphere Reserve in Durango, México (26 $41^{\prime} 01.65^{\prime \prime}$ north; $103^{\circ} 44^{\prime} 37.38^{\prime \prime}$ west, $1149 \mathrm{~m}$ altitude), described as a shrub steppe, dominated by Pleuraphis mutica (Buckl.) Benth enclose with Bouteloua barbata (Vasey); B. curtipendula (Michx.) Torr; B. aristidoides (HBK) Griseb; Aristida spp, Eragrostis spp, and Chloris sp. Add to shrubs and forbs like Prosopis glandulosa 
Torr and Hoffmancegia densiflora Gray, Larrea tridentata (DC) Cov, and Kallstroemia grandiflora Gray as well as Ziziphus obtusifolia (T. \& G.) Gray, Opuntia rastrera Weber, Haplopapus heterophilus (Gray) Blake, Tidestromia gemmata (I. M.) Johnst, Sida leprosa (Orth.) K. Schum and Salsola kali L.

B. nubilum can be found in grasslands from West Montana, USA to North of Mexico. In the study site this species is an important dimorphic medium size grassho-

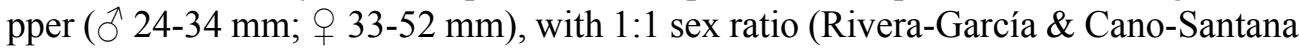
2009). Adult males are shining black, whereas commonly females are dark brown or pale brown, although some are black; female color proportion brown to black were 4:1 $(\mathrm{N}=800)$, tend to form large aggregations when outbreaks occurs (RiveraGarcía 2009). Swarms were recorded in Mapimí arid grasslands during 1980, 1981, 1992, 1993, 1998, 1999 and 2005 (Rivera-García 1986, 2006). During 1998 and 1999 summers, Rivera-García \& Cano-Santana (2009) observed and estimated B. nubilum population swarms from last nymph stage. The highest density was recorded for later authors in 1998 with $35.81 \pm$ e. d. $35.20 \mathrm{ind} / \mathrm{m}^{2}(\mathrm{n}=70)$ and its wandering area was estimated 200 has. The weather during 1998 and 1999 was drier than the regional mean ( $\mathrm{T}_{\text {mean }} 20.5,20.1^{\circ} \mathrm{C}$; rainfall 157 and $177.2 \mathrm{~mm}$, evaporation: 3, 285 and 3, 149 $\mathrm{mm}$, respectively).

Observations on $B$. nubilum vertebrate predators were made every four days into the wandering area, during four hours at different times during a day by direct observations, between 08:00 to 20:00 hrs, in two blocks of four plots of $36 \times 36 \mathrm{~m}$ each one, with approximately $50 \mathrm{~m}$ between them, and $500 \mathrm{~m}$ between blocks, from mid September to mid October during 1998, 1999, and 2005. The invertebrate predators observed preying on $B$. nubilum were separated from those collected at the work area using 20 pitfall traps by plot; reviewed every 12 hours by two periods of five days. All predator species were identified and catalogued in a database. The predators to $B$. nubilum were as follows:

Reptile. Five species were observed preying on B. nubilum: Collard lizard, Crotaphytus collaris (Say); Prairie lizard, Sceloporus undulates (Latreille); Little striped whiptail, Cnemidophorus inornatus Baird; Western whiptail, C. tigris Baird \& Girard; and Texas spotted whiptail, C. gularis scalaris Cope. The most common (considering the three years) were Cnemidophorus inornatus, C. gularis scalaris, and C. tigris.

Amphibians. Only two species were recorded, Great Plains toad, Bufo cognatus Say, and Couch's spade foot, Scaphiopus couchii Baird; these species were not present in 2005 .

Birds. This group was the most diverse, there were 20 species observed feeding $B . n u$ bilum: Grasshopper sparrow, Ammodramus savanarum (Gmelin); Verdín, Auriparus 
flaviceps (Sundevall); Cactus wren, Camphylorhynchus brunneycapilus (Lafresnaye); Canyon wren, Catherpes mexicanus (Swainson); Hermit warbler, Dendroica occidentalis (Towsend); Scott's oriole, Icterus parisorum Bonaparte; Loggerhead shrike, Lanius ludovicianus L.; Ash-throated flycatcher, Myarchus cinarecens (Lawrens); Blue-gray gnatcatcher, Polioptila caerulea L.; Vermilion flycatcher, Pyrocephalus rubinus (Boddaert); Rock wren, Salpinctes absoletus (Say); Say's phoebe, Sayornis saya (Bonaparte); Bewick's wren, Thryomanes bewickii (Aubdubon); Curve-billed thrasher, Toxostoma curvirostre (Seainson); Cassin's kingbird, Tyranus vociferans Swainson; Greater roadrunner, Geococcys californianus (Lesson); Swainson's hawk, Buteo swansonii Bonaparte; Red-tailed hawk, B. jamaicensis (Gmelin); Common raven, Corvus corax L., and American kestrel, Falco sparverius L.

Mammals. In order to recognize these organisms as predators of $B$. nubilum, was necessary to use two methods; checking its scats there were found the following two records: Coyote, Canis latrans Say; Grey fox, Uriocyon cineroargentatus (Schreber); and by direct observations: hooded skunk, Mephitis macroura (Schreber); Mexican ground squirrel, Spermophilus mexicanus (Erxleben), and Spotted ground squirrel, $S$. spilosoma Bennett. The last ones are unusual grasshopper consumers.

Diurnal arthropods. Coleoptera: Ground beetle, Pasimachus punctatus Haldeman; Blister beetle, Pyrota postica Le Conte; Blister beetles, Epicauta spp. Diptera: Robber flies, Efferia spp. Mantodea: Mantid, Stagmomantis limbata (Hann). Hemiptera: Thread-legged bug, Zelus socus Uler. Aranea: Cross spider. Araneus sp.; Black and yellow garden spider, Argiope auraentia Lucas; Borrowing wolf spiders, Gelycosa spp.; Thin-legged wolf spiders, Pardosa spp., and two un-determined Trap-door spiders of the family Ctenisidae.

Nocturnal arthropods. Aranea: Tarantula, Aphonopelma sp. Scorpiones: Centuroides scorpion, Centuroides elegans (Thorell); Vaejovis scorpion, Vaejovis coahuilae Williams, and Black scorpion $V$. mexicanus Koch.

ACKNOWLEDGMENTS. Thanks to the Herrera family and Cuauhtémoc Domínguez for their help at field, and to Alfredo Garza, Elizabeth Aragón and Rolando González for their help and knowlege on vertebrate identification.

\section{LITERATURE CITED}

Branson, D. H. 2005. Direct and indirect effects of avian predation on grasshopper communities in Northern mixed-grass prairie. Environmental. Entomology, 34: 1114-1121.

Fowler, A. C., R. L. Knight, T. L. George \& L. C. McEwen. 1991. Effects of avian predation on grasshopper populations in North Dakota grasslands. Ecology, 72: 1775-1781. 
Fuller, R. \& A. Joern. 1996. Grasshopper susceptibility to predation in response to vegetation cover and patch area. Journal of Orthoptera Research, 5: 175-183.

Joern, A. 1986. Experimental study of avian predation on coexisting grasshopper populations (Orthoptera: Acrididae) in a Sandhills grassland. Oikos, 46: 243-249.

McEwen, L. C., B. E. Petersen \& C. M. Althouse. 2000. Birds and Wildlife as grasshopper predators, 4 pp. In: G. L. Cunnigham, M. W. Sampson (Eds.). Grasshopper Integrated Pest Management. USDA-APHIS. Technical Bulletin No. 1809.

Mooney, K. A. 2006. The disruption of an ant-aphid mutualism increases the effect of bird on pine herbivores. Ecology, 87: 1805-1815.

Mooney, K. A. \& Y. B. Linhart. 2006. Contrasting cascade: insectivorous birds increase pine but not parasitic mistletoe growth. Journal of Animal Ecology, 75: 350-357.

Otte, D. \& A. Joern. 1975. Insect territoriality and its evolution: population studies of desert grasshoppers on creosote bushes. Journal of Animal Ecology, 44: 29-54.

Pitt, W. C. 1999. Effects of multiple vertebrate predators on grasshopper habitat selection: trade-offs due to predation risk, foraging, and thermoregulation. Evolutionary Ecology, 13: 499-515.

Rees, N. E. 1973. Arthropod and Nematode parasites, parasitoids and predators of Acrididae in America North of Mexico. U. S. Department Agriculture Technical Bulletin. 460 p.

Rivera-García, E. 1986. Estudio faunístico de los Acridoidea de la Reserva de la Biosfera de Mapimí, Dgo. México. Acta Zoológica Mexicana (n.s.), 14: 1-12.

Rivera-García, E. 2006. An Annotated checklist of some orthopteroid insects of Mapimí Biosphere Reserve (Chihuahuan Desert), México. Acta Zoológica Mexicana (n. s.), 22: 131-149.

Rivera-García, E. 2009. Factores que determinan la estructura de la comunidades de chapulines (Orthoptera: Acridoidea) en el Desierto Chihuahuense. Tesis Doctoral, Doctorado en Ciencias (Biología), Facultad de Ciencias UNAM. 125 pp.

Rivera-García, E. \& Z. Cano-Santana. 2009. Efecto de la interferencia parcial en la depredación natural sobre una comunidad de acrídidos en un pastizal del Desierto Chihuahuense. Acta Zoológica Mexicana (n. s.), 25: 345-357.

Van Bael, S. A. \& J. D. Brown. 2005. The direct and indirect effects of insectivory by birds in two contrasting Neotropical forests. Oecologia, 145: 658-668.

\section{Eduardo RIVERA-GARCíA}

Instituto de Ecología, A. C. (INECOL),

Red de Interacciones Multitróficas.

Antigua carretera a Coatepec No. 351.

El Haya, Xalapa 91070 Veracruz, México.

<eduardo.rivera@inecol.edu.mx> 